\title{
高速道路予定地選定の一般的指針としてのハビタット影響評価の試み
}

\author{
今西純一 ${ }^{1} \cdot$ 森本幸裕 $^{1}$ \\ ${ }^{1}$ 京都大学大学院農学研究科 606-8502 京都市左京区北白川追分町 \\ (imanishi@kais.kyoto-u.ac.jp)
}

\section{A habitat impact estimation procedure as a general guide for highway route selection}

\author{
Junichi Imanishi ${ }^{1}$ and Yukihiro Morimoto ${ }^{1}$ \\ ${ }^{1}$ Graduate School of Agriculture, Kyoto University, Oiwake-Cho, Kitashirakawa, Sakyo-Ku, Kyoto, 606-8502 Japan
}

\begin{abstract}
It is essential to estimate and avoid the impacts of large structures on ecosystems from an early planning stage. Although detailed and long-termed data collection is desirable, conducting such intensive surveys at a number of locations during the initial stage of highway route selection is not realistic. Conventional ecological assessment methods essentially have positive values; however, a holistic point of view for biodiversity protection is currently missing. With these concerns in mind, we carried out research on the procedure to estimate the relative impacts of highway alternative routes on habitats as a general guide for initial route selections. The estimation procedure incorporated habitat dependency indices of species groups that were hypothetically established from landscape ecological studies. We conducted a case study along US highway 93 in the Flathead Reservation, Montana, U.S.A. to observe the resourcefulness of the results in relation to the sensitivity of the 2 parameters: the assigned habitat values and the road-effect width. The consistency in the rank of the routes indicated that the estimation method can potentially be used as a general guide for a highway planning. The effects of the sets of the habitat value numbers were to operate HDIs with the numbers of grid cells and to change the degree of agreement for a longer route. The general effect of the widths of road-effect zone was to increase or decrease the difference of the estimated habitat impacts of 2 routes. Narrower buffer zones created the greater difference. The use of landscape ecological species groups has the merit of the holistic approach of the procedure. The complementary use of the estimation procedure will enhance the conventional approach that relies on rarity, typicality and ecological rank of species. Further research with actual field data was necessary to examine the detailed characteristics of the habitat impact estimation procedure.
\end{abstract}

Key words: Geographic Information System (GIS), Ecologica Impact Assessment, Habitat Dependency Index (HDI), Habitat Impact Estimation, Highways

はじめに

高速道路等の大規模構造物の建設にともない, 計 画初期段階から生態系への影響を評価し，その影響 を回避することは欠かせない. 生態学的評価におい て，できるだけ詳細で長期間にわたる調查が望まし いことは自明であるが, そのような集中的調查を高 速道路ルート選定の初期段階で多数の場所において 行うことは現実的ではない.ルート選定初期段階の 一般的指針として高速道路の代替ルートがハビタッ トに与える影響を相対的に評価する一手法を提案し た.

高速道路の野生生物のハビタットにたいする影響 評価は, 大気污染や騒音の評価と比較し, 環境影響 評価のルーティーンに通常あまりうまく組み込まれ ていない. 生態系影響評価のもっとも一般的な方法 に, プロジェクトが選定種（通常は稀少種やアンブ レラ種）のハビタットに与える影響を評価するもの がある(例 Gerrard et al. 2001; Wu and Smeins 2000). これらは，危機的状態のハビタットや絶堿危惧種の 保全が生物多様性保全の観点から最も優先されると いう事実を反映している。しかしながら，このアプ
ローチでは，選定種のハビタットが他の多くの種の ハビタットと重複するところがない場合, 必ずしも それら多くの種を守ることにつながらない可能性が ある.

もちろん，選定種を用いた生態系影響評価手法には メリットがあり, ハビタット影響評価に際しては相 補的に用いるべきである。しかし，われわれは生物 多様性の保全に全体論的な視点が不足していたこと を指摘したい. 本評価手法は, 景観生態学的知見に 基づき設定された生物種群とそのハビタット依存度 指数 (habitat dependency index（HDI））を用小, 全体 論的アプローチを具体化したものである.

\section{評価手法の手順}

高速道路ルートのハビタット影響評価手法の手順 は次の通りである.

1)評価対象域を決定する (人為的境界線よりも, 分 水嶺のような自然の境界線が望ましい)

2) 現状土地被覆レイヤーを作成する

3）ハビタット影響評価のための生物種群を設定する

（後述の事例では, 4 つの生物種群を設定） 
4）各土地被覆にたいする各生物種群のハビタットバ リューレベルを定義する（ハビタットバリューマ トリックス (表 2). 後述の事例では, 最低, 低, 中, 高の 4 段階のハビタットバリューレベルを設 定）

5）各生物種群について, 現状土地被覆レイヤーから, ハビタットバリューマトリックスに基づき, 各ハ ビタットバリューレベルに0（最低）から 1 (高) までのあいだの数值を割り当てたハビタットイン パクトレイヤーを作成する

6) 各生物種群の HDI を算出する

7)道路影響幅を設定する

8) 各生物種群のハビタットインパクトレイヤーの值 に HDI を乗算する（HDI による生物種群の重みづ け：全生物種群のレイヤーを合算した図例, 図 4) 9）道路影響範囲内にある，HDIにより重みづけられ たハビタットインパクトレイヤーの值を合算し, ハビタットインパクトとする（ここで各ルートの ハビタットインパクトが求まる)

10) 2 つの変数（手順 5 のハビタットバリュー数值, 手順 8 の道路影響幅）を変化させ, 手順 5 から 10 を繰り返して, 変数に対する感度の解析を行う(こ
こで変数の值を変化させた場合の各ルートのハビ タットインパクトが求まる)

11）感度解析の結果をあわせて, 各ルートのハビタッ トインパクトの結果を評価する

本評価手法では，一般的ケースとしてプロジェク 卜対象域の生態学的データは不足しているものとの 前提を置いたが，アメリカのハビタット適合指数 (Habitat Suitability Index; HSI) モデルのような個別の ハビタットモデルを手順 2 から 5 に置きかえること も可能である。この場合, 各生物種群からそれぞれ 数種の種を選定することが望ましい.

ハビタット传存度指数（habitat dependency index (HDI)）は,このハビタット影響評価手法のために 考案された. HDI は，評価対象域においてある生物 種群が特定の地域に依存している程度を表す指数と して定義される，HDI は，ある生物種群にとって価 值のあるハビタットの評価対象域内における稀少性 を反映している. $\mathrm{i}$ 番目の生物種群の $\mathrm{HDI}\left(\mathrm{D}_{\mathrm{i}}\right)$ は次 の式から計算される.

$$
D_{i}=\frac{R_{i}}{\sum_{i=1}^{k} R_{i}}
$$

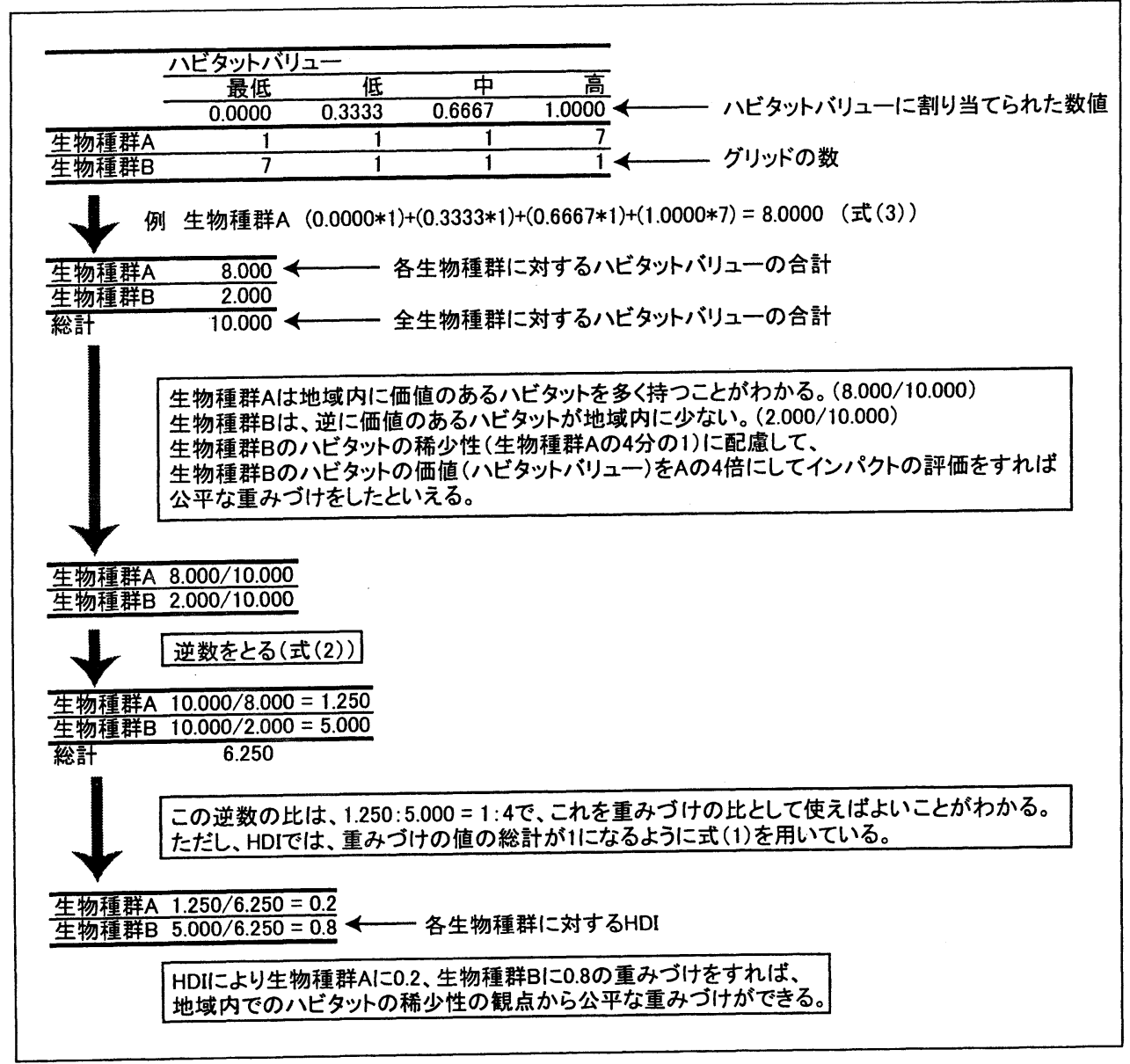

図 1。簡単な例による HDI の算出過程の説明 


$$
\begin{aligned}
& R_{i}=\left(\frac{V_{i}}{\sum_{i=1}^{k} V_{i}}\right)^{-1} \\
& V_{i}=\sum_{j=1}^{n} a_{j} N_{j}
\end{aligned}
$$

$\mathrm{R}_{\mathrm{i}}$ は, 全生物種群のハビタットバリューの合計 $\left(\sum_{\mathrm{i}=1}^{\mathrm{k}} \mathrm{V}_{\mathrm{i}}\right)$ にたいする $\mathrm{i}$ 番目の生物種群のハビタットバ リューの合計 $\left(\mathrm{V}_{\mathrm{i}}\right)$ の比率の逆数, $\mathrm{k}$ は生物種群の数で ある. i 番目の生物種群にたいするハビタットバリュ 一の合計 $\left(\mathrm{V}_{\mathrm{i}}\right)$ は, 手順 5 において $\mathrm{j}$ 番目のハビタッ トバリューレベル（後述の事例では, 最低, 低, 中, 高のそれぞれ）に割り当てられた数值 $\left(\mathrm{a}_{\mathrm{j}}\right)$ と, 評価対 象域内において $\mathrm{j}$ 番目のバリューを持つグリッドの 数 $\left(\mathrm{N}_{\mathrm{j}}\right)$ から計算される. $\mathrm{n}$ はハビタットバリューのレ ベルの数（後述の事例では，最低，低，中，高の 4 つ）である. HDI は $\mathrm{D}_{\mathrm{i}}$ の合計が 1 になるように定義 されている.

$$
\sum_{i=1}^{k} D_{i}=1
$$

それゆえに, HDI は異なる生存戦略とハビタット依 存度をもつ生物種群のハビタットインパクトレイヤ 一を統合する際の客観的な重みづけの数值として利 用することが可能である. 簡単な概念的な例を用い HDI の算出過程を図 1 に示した.

\section{事例による検討}

アメリカ合衆国モンタナ州フラットヘッド特別保 留地を通る US highway 93 を事例に，提案した手法 の結果の有用性と $2 つ の$ 変数（割り当てられたハビ タットバリュー数值と道路影響幅）の感度について 考察した（図 2). 対象とした高速道路は, 森林, 草 地，水などさまざまなタイプのハビタットに囲まれ ている. 野生生物へのインパクトを低減するように, 連邦および州当局と特別保留地政府は, ルートを新 設する選択肢を含め既存ルートの再設計を進めてい る (Jones 2001).

既存ルートは保留地の南にあるエバロ（Evaro）か

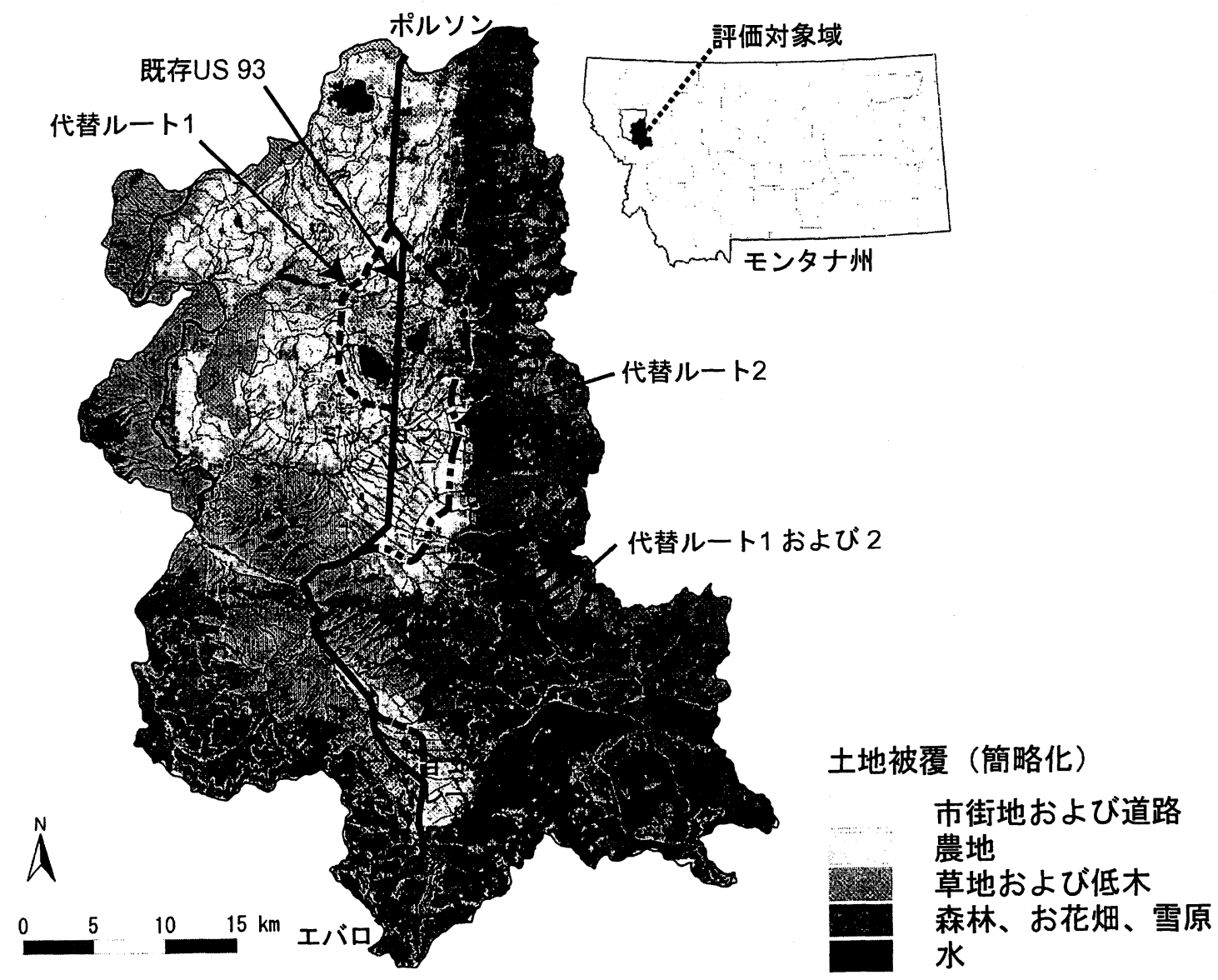

図 2．アメリカ合衆国モンタナ州フラットヘッド特別保留地における US93 既存ルートと $2 つ の$ 代替ルート: 印刷の都合上, 土地被覆カテゴリーは簡略化されている. 
表 1. テータセット

\begin{tabular}{|c|c|c|c|c|}
\hline データセット名 & 提供機関 & 属性 & デー夕形式 & スケール \\
\hline 1 7.5-Minute Digital Raster Graphic & U.S. Geological Survey & 地形図 & 画像イメージ & $1: 24000$ \\
\hline 2 Montana 90-meter Land Cover Pixels From the Gap Analysis Project & Wildlife Spatial Analysis Lab., Univ. of Montan & :土地被覆 & $90 \mathrm{~m}$ グリッド & $1: 100000$ \\
\hline 3 Census 2000 TIGER Hydrography Lines & U.S. Census Bureau & 水面 & 線 & $1: 100000$ \\
\hline 4 Census 2000 TIGER Road Lines & U.S. Census Bureau & 道路 & 線 & $1: 100000$ \\
\hline
\end{tabular}

ら, ジョコーバレー (Jocko Valley), ミッションバ レー（Mission Valley）を通り,フラットヘッド湖の 南側に位置するポルソン (Polson) 近郊に到達する. ミッションバレーの真ん中にはケトルポンドと呼ば れる季節的あるいは通年の多数の湿地がある．評価 対象域は保留地内の 3 つの分水嶺 (総計 $2392 \mathrm{~km}^{2}$ ) か らなる.われわれはケトルポンドを迁回する $2 つ の$ 代替ルートを実験的に設置した。それらのルートは 保留地内の生態学的ミティゲーションになると考え られている(Jones 2001, 図2).

前項で述べた手順に従い，既存および代替ルート のハビタットインパクトの評価を行った. GIS ソフ トには ArcView 3.1（ESRI 社）を使用した. 入手し たデータセットは表 1 の通りである. 7.5-minute Digital Raster Graphics は, ケトルポンドをディジタ イズする際のベースマップとして使用した. 2 車線

（片側 1 車線）の高速道路は, 車道と路肩で $13.2 \mathrm{~m}$ の幅を, 農村地域で推奖される分離帯の幅を含めれ
ば 31.2m の幅を必要とする (Baker et al. 1975)．本研 究においては $16.8 \mathrm{~m}$ の分離帯を持つ 2 車線高速道路 （つまり 30m 幅の高速道路）を仮定した．ちなみに 既存の高速道路も 2 車線である．われわれは, 空間 精度のレベルを制限している GAP 土地被覆データ の解像度が $90 \mathrm{~m}$ であることに注意を払いながらも, 高速道路の幅, TIGER Hydrography Lines の河川の幅

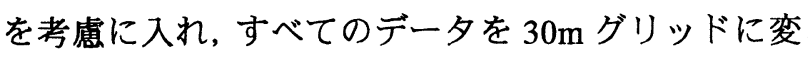
換した。

手順 3 においては, ジェネラリストおよびエッジ 種, 森林内部種, 草原種, 河畔および水系種の 4 つ の生物種群を選定した. ジェネラリストおよびエッ ジ種は，頻繁な擋乱に耐え，ランドスケープにあり ふれた種である(Forman 1995)。森林内部種と草原種 は，道路によるハビタットの破壊や劣化を含む擋乱 にたいしより敏感であり (Brody and Pelton 1989; Reijnen et al. 1995; Keyser et al. 1998)，それぞれ森林 内部と草原に分布する. 河畔および水系種は, 一般

表 2. ハビタットバリューマトリックス

\begin{tabular}{|c|c|c|c|c|}
\hline & $\begin{array}{l}\text { ジェネラリスト } \\
\text { およびエッジ種 }\end{array}$ & 森林内部種 & 草原種 & $\begin{array}{c}\text { 河畔およひび氷系 } \\
\text { 種 }\end{array}$ \\
\hline 市街地 & 低 & 最低 & 最低 & 最低 \\
\hline 農地 & 中 & 最低 & 低 & $\begin{array}{c}\text { 隣接 } \\
\text { その低 } \\
\text { そ他 最低 }\end{array}$ \\
\hline 草原 & 高 & 最低 & 高 & $\begin{array}{c}\text { 隣接 高 } \\
\text { その他 最低 }\end{array}$ \\
\hline 低木 & 高 & 低 & 中 & $\begin{array}{c}\text { 隣接 高 } \\
\text { その他 最低 }\end{array}$ \\
\hline 森林 & $\begin{array}{l}0-450 \mathrm{~m} \text { 高 } \\
450 \mathrm{~m} \text {-中 }\end{array}$ & $\begin{array}{l}0-450 \mathrm{~m} \text { 中 } \\
450 \mathrm{~m}-\text { 高 }\end{array}$ & $\begin{aligned} & \text { 隣接 } \text { 中 } \\
& \text { その他 } \text { 最低 } \\
&\end{aligned}$ & $\begin{array}{c}\text { 隣接 高 } \\
\text { その他 最低 }\end{array}$ \\
\hline 水 & $\begin{array}{cl}\text { 隣接 } & \text { 高 } \\
\text { その他 } & \text { 最低 }\end{array}$ & $\begin{array}{c}\text { 隣接 高 } \\
\text { 河川 中 } \\
\text { その他最低 }\end{array}$ & 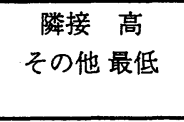 & 高 \\
\hline 河畔林 & $\begin{array}{l}0-450 \mathrm{~m} \text { 高 } \\
450 \mathrm{~m} \text { - 中 }\end{array}$ & $\begin{array}{l}-450 \mathrm{~m} \text { 中 } \\
450 \mathrm{~m} \text { - 高 }\end{array}$ & 高 & 高 \\
\hline 裸地 & 低 & 低 & 低 & $\begin{array}{c}\text { 隣接 低 } \\
\text { その他 最低 }\end{array}$ \\
\hline お花畑 & 中 & 低 & 最低 & $\begin{array}{c}\text { 隣接 低 } \\
\text { その他 最低 }\end{array}$ \\
\hline 雪原 & 低 & 低 & 最低 & $\begin{array}{c}\text { 隣接 低 } \\
\text { その他 最低 }\end{array}$ \\
\hline 道路 & $\begin{array}{l}\text { 高速道路 最低 } \\
\text { ローカル 低 }\end{array}$ & 最低 & $\begin{array}{l}\text { 高速道路 最低 } \\
\text { ローカル 低 }\end{array}$ & 最低 \\
\hline
\end{tabular}

「隣接」グリッドは、「最低」のバリューを含まないカテゴリーのグリッドに隣接するグリッ ドを表す。例えば、草原種、森林の「隣接」グリッドは、農地、草原、低木、河畔林、裸地に 隣接する森林のグリッドを表す。 
的に陸上生態系では空間的に制限されている水体に 依存する(Vos and Chardon 1998). 評価対象域に潜在 的に存在する種としては，ジェネラリストおよびエ ッジ種としてはレッドフォックス(Vulpes vulpes)と アメリカムシクイ(Dendroica petechia), 森林内部種 としてはグレイウルフ(Canis lupus)とグリズリーベ ア(Ursus arctos horribilis), 草地種としてはりウゲン ハヤブサ (Falco mexicanus) とプロングホーン (Antilocapra americana), 河畔および水系種としては アメリカビーバー(Castor canadensis)とブルトラウ ト(Salvelinus confluentus)などが含まれるが，個々の 生物種の分布デー夕は不足しており，それぞれの生 物種群が同様の生息パターンを持っているとの仮定 を置いた。

手順 4 において, 評価対象地のハビタットバリュ 一マトリックスは表 2 のように定義された。各生物 種群にたいし 4 つのハビタットバリューレベル（つ まり，その生物種群にたいする 4 つのインパクトレ
ベル）が設定された. 森林および河畔林内部に到達 するエッジ効果の距離には, 野生生物への悪影響は 森林の端から 300 から $600 \mathrm{~m}$ に及ぶという Wilcove et al.（1986）の結果から，450m を設定した.

手順 5 においては, 4 つの数值（0-1）がハビタッ トバリューレベルに割り当てられた。感度解析のた め本事例においては，4 つの数值のセットには $y=x^{\mathrm{n}}(\mathrm{n}: 1 / 3,1 / 2,1,2,3,4,5,6)$ の曲線に由来する

数値を設定した(図 3).

手順 8 においては, 感度解析のため道路影響幅に は「道路外側の線から $990 \mathrm{~m}$ のバッファゾーン (2020m の道路影響幅)」「道路外側の線から $330 \mathrm{~m}$ のバッファゾーン」「道路外側の線から $90 \mathrm{~m}$ のバッ ファゾーン」「バッファゾーンなし（30m の道路影響 幅)」の 4 つを設定した. $990 \mathrm{~m}$ のバッファゾーンの 幅は, 道路サイド種の侵入距離, あるいは野生生物, 野火, 敏感なハビタットに影響を与える人間の侵入

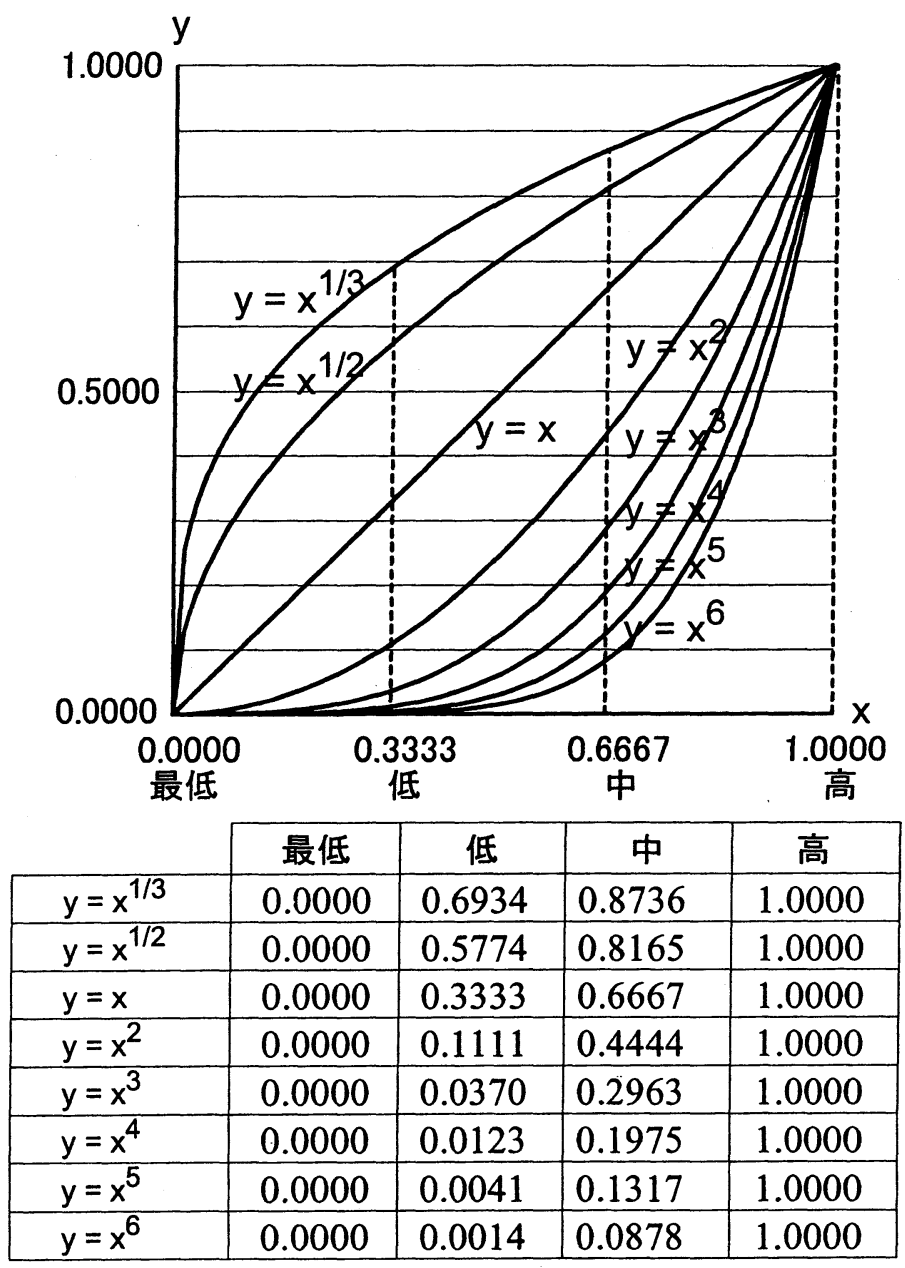

図 3.8つの曲線と 4 つのハビタットバリューレベルに割り当てられた数值 :「最低」と「高」にはそれぞれ 0.00000 と 1.0000 を,「低」と「中」には, 各曲線の $\mathrm{x}=0.3333$ と $\mathrm{x}=0.6667$ の時の $\mathrm{y}$ の值を割り当てた. 
表 3 ．異なるハビタットバリュー数値のセットによる 4 つの生物種群の HDI

\begin{tabular}{lcccccccc}
\hline & \multicolumn{7}{c}{ ハビタットバリー数值の決定に使用した曲線 } \\
\cline { 2 - 8 } & $\mathrm{y}=\mathrm{x}^{1 / 3}$ & $\mathrm{y}=\mathrm{x}^{1 / 2}$ & $\mathrm{y}=\mathrm{x}$ & $\mathrm{y}=\mathrm{x}^{2}$ & $\mathrm{y}=\mathrm{x}^{3}$ & $\mathrm{y}=\mathrm{x}^{4}$ & $\mathrm{y}=\mathrm{x}^{5}$ & $\mathrm{y}=\mathrm{x}^{6}$ \\
\hline $\begin{array}{l}\text { ジェネラリスト } \\
\text { およびエッジ種 }\end{array}$ & 0.0850 & 0.0848 & 0.0847 & 0.0858 & 0.0873 & 0.0885 & 0.0893 & 0.0898 \\
\hline 森林内部種 & 0.1572 & 0.1599 & 0.1690 & 0.1891 & 0.2085 & 0.2251 & 0.2383 & 0.2481 \\
\hline 草原種 & 0.1581 & 0.1631 & 0.1757 & 0.1898 & 0.1942 & 0.1944 & 0.1933 & 0.1920 \\
河畔および水系種 & 0.5998 & 0.5922 & 0.5707 & 0.5354 & 0.5100 & 0.4920 & 0.4791 & 0.4701 \\
\hline
\end{tabular}

の距離 (Forman et al. 1995) に対応する近似值である. $330 \mathrm{~m}$ の幅は, 10000 台/日の交通密度を持つ道路に おける，森林および草地の鳥類にたいする平均道路 影響幅 (Forman and Alexander 1998) と近似する.ちな みに, US93 の研究対象範囲の 2004 年における予測 平均日交通量は, 最も多い箅所で 13480 台/日, 最も 少ない箇所で 7190 台である. $90 \mathrm{~m}$ の幅は, 生態学的 群集に与える確認可能なインパクトのゾーンが $100 \mathrm{~m}$ までであるとよく引用している英国の文献の 数值(Underhill and Angold 2000)の近似である.

\section{結果と考察}

$\mathrm{y}=\mathrm{x}^{\mathrm{n}} \quad(\mathrm{n}: 1 / 3,1 / 2,1,2,3,4,5,6)$ の曲線に由来す る4つのハビタットバリュー数值の 8 セットを用い, 計算された HDI は表 3 の通りである. HDI は, ジェ ネラリストおよびエッジ種では 0.085 から 0.090 , 森 林内部種では 0.16 から 0.24 , 草地種では 0.16 から 0.19, 河畔および水系種では 0.47 から 0.60 の範囲 をとった. どのハビタットバリュー数值のセットに おいても, ジェネラリストおよびエッジ種の HDI は 最も低く, 河畔および水系種の HDIは最も高かった. この結果は，ジェネラリストおよびエッジ種の耐拱 乱性と, 河畔および水系種に適したハビタットの評 価対象域における稀少さによるものであると思われ
た. 森林内部種および草原種の HDI は中間的であっ た. 森林内部種の HDI は $\mathrm{y}=\mathrm{x}^{\mathrm{n}}(\mathrm{n} \geq 3)$ に由来する数 値のセットを用いると, 草原種の HDI より大きくな った. nの值が大きくなると,「中」程度のインパク トのグリッドの影響の相対的な大きさは,「低」いイ ンパクトのそれに比較し，增大する（図 3）。それゆ えに,より多くの「中」程度のインパクトのグリッ ドとより少ない「低」いインパクトのグリッドを持 つ森林内部種（表 4）の HDI は，ハビタットバリュ 一数值のセットに草地種とは異なる感度の傾向を示 した.

重みづけされた全生物種群のハビタットインパク トレイヤーでは, 河川とケトルポンドがインパクト の最も高い地域で, 湖や貯水池がインパクトの高い 地域であった（図 4)。草地や低木, 森林は中間程度 のインパクトを持つ地域であったが，草地と森林内 部は, 低木や森林緑部より高いインパクトを持って いた.これらの特徴は, 異なるハビタットバリュー 数值のセットにおいても一貫していた.

既存ルート，代替ルート 1 および 2 の総延長はそ れぞれ $80.5 \mathrm{~km}, 85.1 \mathrm{~km}, 89.2 \mathrm{~km}$ であった.さまざ まなハビタットバリュー数值および道路影響幅を用 いて評価されたハビタットインパクトは, 表 5 の通 りであった. 全体的に，既存ルートのインパクトは

表 4.4つの生物種群にたいするハビタットインパクトレイヤーのグリッド数

\begin{tabular}{lcccr}
\hline & \multicolumn{3}{c}{ ハビタットバリュー/インパクト } \\
\cline { 2 - 5 } & 最低 & 低 & 中 & 高 \\
\hline $\begin{array}{l}\text { ジェネラリスト } \\
\text { およびエッジ種 }\end{array}$ & 33272 & 153539 & 932786 & 1528523 \\
\hline 森林内部種 & & & & \\
& 1175241 & 149260 & 812111 & 511508 \\
\hline 草原種 & 1122821 & 603889 & 185048 & 736363 \\
河畔および氷系種 & 2283595 & 56892 & 0 & 307634 \\
\hline
\end{tabular}




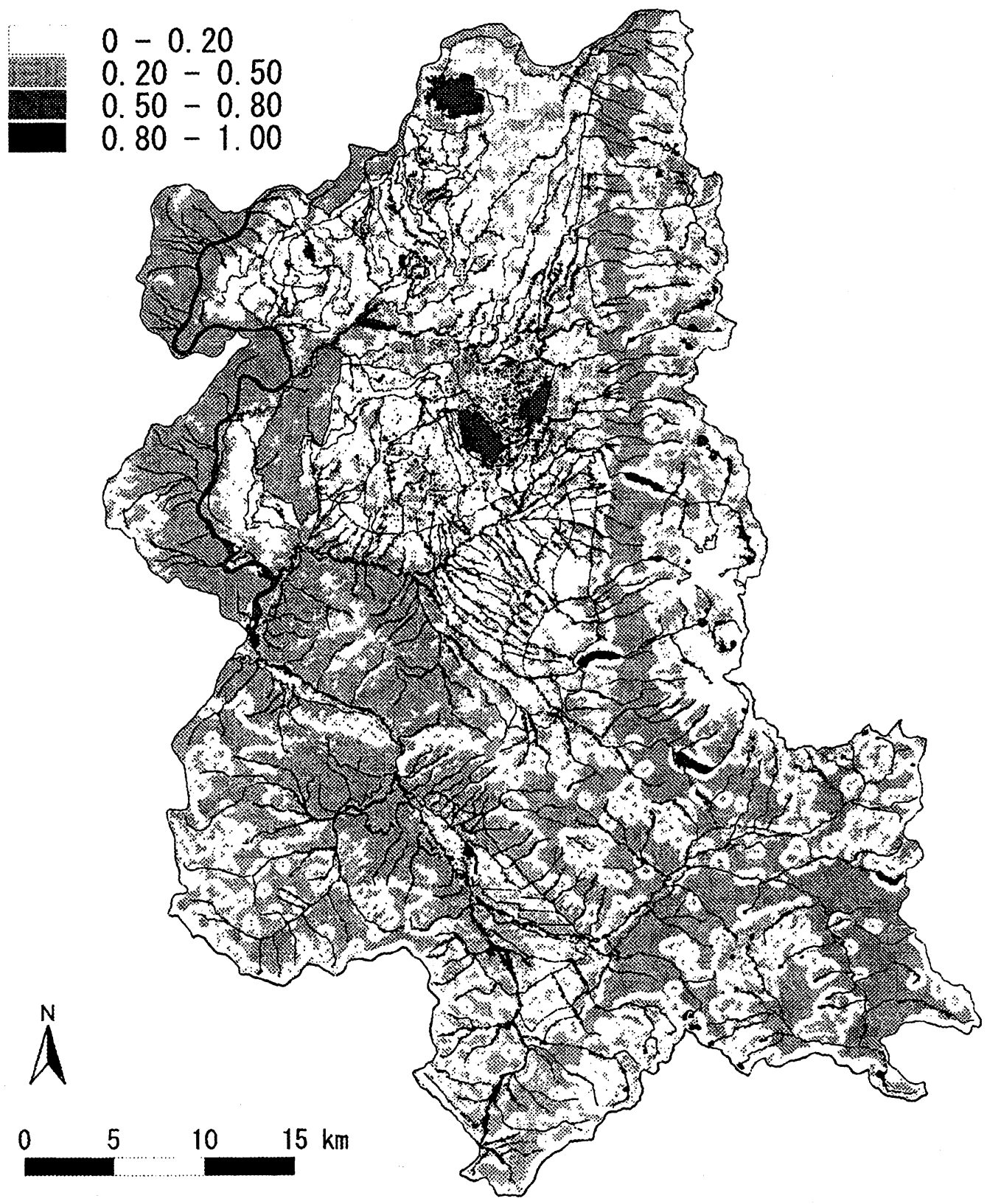

図 4.HDI による重みづけ済みハビタットインパクトレイヤー（ハビタットバリューの数值の割り当てに利 用した曲線は $\mathrm{y}=\mathrm{x}^{2}$ : インパクトの值は 0.00 から 1.00 までの笔囲の数值をとる. 0.00 が最もインパクト が低く, 1.00 が最もインパクトが高い.

表 5．異なるハビタットバリュー数值と道路影響幅による 3 ルートのハビタットインパクト

\begin{tabular}{|c|c|c|c|c|c|c|c|c|c|c|c|c|c|}
\hline & バッファ幅 & \multicolumn{3}{|c|}{$0 \mathrm{~m}$} & \multicolumn{3}{|c|}{$90 \mathrm{~m}$} & \multicolumn{3}{|c|}{$330 \mathrm{~m}$} & \multicolumn{3}{|c|}{$990 \mathrm{~m}$} \\
\hline & ルート & 既存 & 代替1 & 代替2 & 既存 & 代替1 & 代替2 & 既存 & 代替1 & 代替2 & 既存 & 代替1 & 代替2 \\
\hline \multirow{8}{*}{ 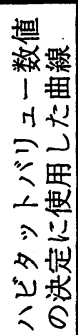 } & $y=x^{1 / 3}$ & 100.0 & 93.5 & 101.9 & 100.0 & 94.2 & 97.7 & 100.0 & 96.7 & 98.3 & 100.0 & 99.0 & 101.8 \\
\hline & $y=x^{1 / 2}$ & 100.0 & 92.4 & 101.3 & 100.0 & 93.3 & 97.2 & 100.0 & 95.8 & 97.9 & 100.0 & 98.3 & 101.7 \\
\hline & $y$ & 100.0 & 89.5 & 99.3 & 100.0 & 91.0 & 95.9 & 100.0 & 93.5 & 96.7 & 100.0 & 6.4 & 101.2 \\
\hline & $y=x^{2}$ & 100.0 & 85.5 & 96.2 & 100.0 & 87.9 & 93.8 & 100.0 & 90.5 & 94.9 & 100.0 & 4.0 & 100.3 \\
\hline & $y=x^{3}$ & 100.0 & 83.4 & 94.1 & 100.0 & 86.2 & 92.4 & 100.0 & 88.9 & 93.6 & 100.0 & 92.8 & 99.7 \\
\hline & $y=x^{4}$ & 100.0 & 82.3 & 92.7 & 100.0 & 85.3 & 91.4 & 100.0 & 88.1 & 92.8 & 100.0 & 92.1 & 99.2 \\
\hline & $y=x^{5}$ & 100.0 & 81.7 & 91.8 & 100.0 & 84.8 & 90.7 & 100.0 & 76 & 92.2 & 100.0 & 91.8 & 98.8 \\
\hline & $y=x^{6}$ & 100.0 & 81.3 & 91.1 & 100.0 & 84.5 & 90.2 & 100.0 & 87.3 & 91.8 & 100.0 & 91.6 & 98.6 \\
\hline
\end{tabular}

バッファ幅：道路外側線からのバッファーの距離（道路影響幅=バッファ幅 $\times 2+$ 道路幅）

ハビタットインパクトは、各変数の組合わせの中で既存ルートのインパクトを100.0とした場合の相対値 
代替ルートのものに比べて高かった．また，代替ル ート1のインパクトは, 代替ルート 2 のものより低 かった。

異なるハビタットバリュー数值のセットを用いた 結果, ハビタットインパクトの評価にたいする勃果 が以下のように明らかになった。一般的ルールとし ては,ルートの距離が短く, 低いハビタットインパ クトの地域を通れば, そのルートのハビタットイン パクトの評価は低くなる.しかしながら，本事例に おいては, 既存ルートは最短であったがケトルポン ドのようなより高いインパクトの地域を通り, 代替 ルートはより長いがよりインパクトの低い地域を通 っていた．それゆえに，代替ルート 2 は $\mathrm{n}=1 / 3,1 / 2$, 1 あるいは 2 のような小さな $\mathrm{n}$ の数值セットを用い たケースのいくつかにおいて, 既存ルートより高い インパクトを持った.この結果は, $\mathrm{n}=3,4,5$ あるい は 6 のような大きな $\mathrm{n}$ の数值セットは, 「低」および
「中」程度のインパクトを持つグリッドに与えられ る数值に比べて,「高」いインパクトを持つグリッド に与えられる数值が相対的に大きくなるので, より 長いルートを支持する傾向があることを示している. 逆に, より小さな $\mathrm{n}$ の数值セットは, より短いルー トを支持した. 図 5 は与えられた数值の効果を説明 する。

道路外側線からのバッファゾーンのさまざまな幅 は, ハビタットインパクトの評価にたいし, 次のよ うな一般的傾向を示した。 すなわち，より狭いバッ ファゾーンは, ハビタットバリューのセットが同一 であれば，ルート間の評価インパクトの差をより大 きなものにしていた. しかしながら,バッファゾー ンなしおよび 990m のバッファゾーンにおいては, いくつかの例外があった. バッファゾーンなしによ る評価は，30m の道路幅のみに依存しており，30m という幅では土地被覆において極端なパターンが現

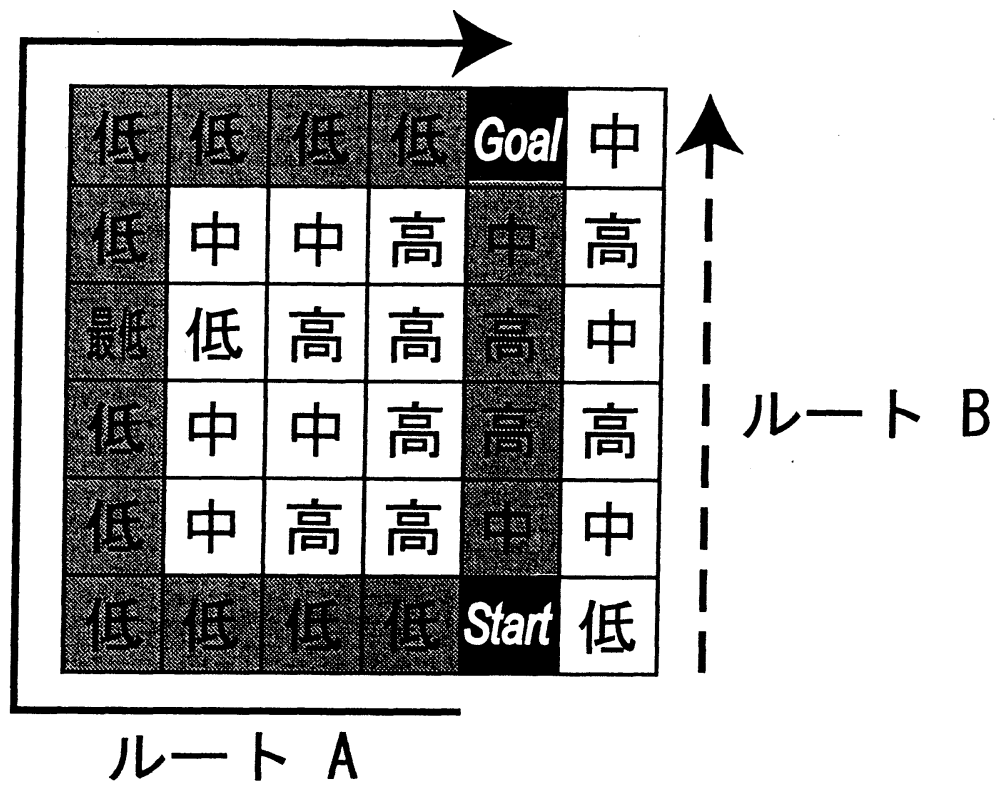

\begin{tabular}{|l|l|r|r|}
\cline { 3 - 4 } \multicolumn{1}{c|}{} & \multicolumn{2}{c|}{\begin{tabular}{c} 
ハビタットバリュー数值 \\
\cline { 3 - 4 } \multicolumn{1}{c|}{}
\end{tabular}} & \multicolumn{2}{|c|}{ の決定に使用した曲線 } \\
\cline { 2 - 4 } & ハビタットインパクト & $\mathrm{y}=\mathrm{x}$ & $\mathrm{y}=\mathrm{x}^{2}$ \\
\hline ルート $\mathrm{A}$ & 最低 $\mathrm{x} 1+$ 低 $\mathrm{x} 11$ & 3.6663 & 1.2221 \\
\hline ルートB & 中 $\mathrm{x} 2+$ 高 $\mathrm{x} 2$ & 3.3334 & 2.8888 \\
\hline
\end{tabular}

図 5.ハビタットバリュー数值のセットの効果 : ルート A はルート B より長い（12グリッド）が, よりイン パクトの低いグリッドを通っている. ルート B は, 最短 ( 4 グリッド) であるが, よりインパクトの高 いグリッドの上を通る. $\mathrm{y}=\mathrm{x}$ の軌跡によるハビタットバリュー数值のセットを用いた結果, ルート $\mathrm{A}$ は ルートBより高いインパクトをもつと算定された。（注記 : 実際のハビタットインパクトレイヤーでは各 生物種群のハビタットバリューが HDI により重みづけられた後, 加算されている. したがって, 最低, 低, 中, 高というように 4 段階に分かれることはほとんどなく, 各段階の中間の值をとることが多い. しかしながら, 本図では, ハビタットバリュ一数值の決定に使用する曲線の影響の全体的な傾向を概念 的にわかりやすく説明するために，上記のような単純化したグリッドを示し，説明している.） 
れやすいことから，ある意味で幾分気まぐれな結果 を生んでいると思われた，例えば, $30 \mathrm{~m}$ 幅の既存の ローカル道路に治った高速道路ルートは，たとえ周 囲の環境がその地方において最もインパクトの高い 地域であったとしても，非常に低いインパクトであ ると評価される可能性がある. $990 \mathrm{~m}$ のバッファゾー ンを用いた評価は, バレーや山脈, 湿地や河川の集 中している地域など評価対象地のなかのより大きな スケールのランドスケープの構造により敏感であっ た.

\section{結 論}

これらの結果からは，2 つの変数（ハビタットバ リュー数值のセットと道路影響幅）のほとんどの組 合せにおいて，3 つのルートの順位は，ハビタット インパクトの高いルートから順に既存ルート，代替 ルート 2, 代替ルート 1 の順であり，その順位に強 い一貫性があることが読み取れた，それゆえに，本 事例の場合, 変数の効果は比較的小さいと考えられ た．結果の一貫性は，本評価手法が高速道路計画初 期段階のルート選定の一般的指針として使用が可能 であることを示唆した.

また, 評価手法における 2 つの変数の効果が明確 になった. ハビタットバリュー数值のセットの効果 は,グリッドの数とともに HDIの值を操作すること， より長いルートにたいする肯定の度合を変化させる

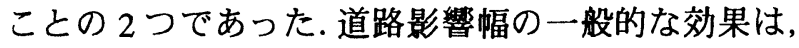
ルート間のハビタット影響評価の差を增加・隇少さ せることであり，より狭い道路影響幅はより大きな 差を作る傾向があった. バッファゾーンなしによる 評価は，極端な土地被覆パターンの影響を強く受け る可能性があった．最も幅の広いバッファゾーンに よる評価は，より大きなランドスケープ構造のパタ ーンを反映していた。

景観生態学的視点から設定された生物種群の使用 は，全体論的アプローチによる評価ができるという メリットがある．本評価手法の相補的使用は，種の 稀少性，典型性，上位性に基づく従来のハビタット 影響評価を補強するであろう。ハビタット影響評価 手法の詳細な特幑を調べるために，実際のフィール ドデータを用いたさらなる検証が必要である.

\section{引用文献}

Baker, R.F. 1975. Handbook of Highway Engineering. Van Nostrand Reinhold, New York. 225-226.

Brody, A.J. and Pelton, M.R., 1989. Effects of roads on
Black Bear movements in western North Carolina. Wildlife Society Bulletin 17: 5-10.

Forman, R.T.T. 1995. Landscape Mosaics. 436pp. Cambridge University Press, New York.

Forman, R.T.T. and Alexander L.E. 1998. Roads and their major ecological effects. Annual Review of Ecology and Systematics 29: 207-231.

Forman, R.T.T., D.S. Friedman, D. Fitzhenry, J.D. Martin, A.S. Chen and Alexander, L.E. 1995. Ecological effects of roads: toward three summary indices and an overview for North America. Proceedings of International Conference on Habitat Fragmentation, Infrastructure and the Role of Ecological Engineering: 40-54.

Gerrard, R., Stine, P. Church, R. and Gilpin, M. 2001. Habitat evaluation using GIS: a case study applied to the San Joaquin Kit Fox. Landscape and Urban Planning 52: 239-255.

Jones, G., 2001. personal communication.

Keyser, A.J., Hill, G.E. and Soehren, E.C. 1998. Effects of forest fragment size, nest density, and proximity to edge on the risk of predation to ground-nesting passerine birds. Conservation Biology12(5): 986994.

Reijnen, R., Foppen, R., Ter Braak, C. and Thissen, J. 1995. The effects of car traffic on breeding bird populations in woodland. III. Reduction of density in relation to the proximity of main roads. Journal of Applied Ecology 32: 187-202.

Underhill, J.E. and Angold, P.G. 2000. Effects of roads on wildlife in an intensively modified landscape. Environmental Review 8: 21-39.

Vos, C.C. and Chardon, J.P. 1998. Effects of habitat fragmentation and road density on the distribution pattern of the moor frog Rana arvalis. Journal of Applied Ecology 35: 44-56.

Wilcove, D.S., McLellan, C.H. and Dobson, A.P. 1986. Habitat fragmentation in the temperate zone. Conservation Biology. (Soule, M.E. ed.) 237- 256. Sinauer Associates, Inc., Sunderland, Massachusetts.

$\mathrm{Wu}$, X.B. and Smeins, F.E. 2000. Multiple-scale habitat modeling approach for rare plant conservation. Landscape and Urban Planning 51: 11-28.

（受付 2002 年 8 月 30 日）

（受理 2002 年 11 月 15 日） 